Original Article

\title{
EFFECT OF BACOSIDE A ON LIPID PEROXIDATION IN D-GALACTOSE INDUCED AGING MICE
}

\author{
SUSHAMA PAWAR*, MANMOHINI JADHAV
}

Department of Zoology, Bharati Vidyapeeth Deemed University, Yashwantrao Mohite College of Arts, Science and Commerce, Pune 411038, Maharashtra, India

Email: zooymc@gmail.com

Received: 30 Dec 2016 Revised and Accepted: 13 Jul 2017

\section{ABSTRACT}

Objective: Bacoside A is a major bioactive constituent of Bacopa monnieri L having antioxidant property. The objective of this study was to evaluate the effect of Bacoside A, on lipid peroxidation in brain, heart and liver during induced aging.

Methods: Male Swiss albino mice, Mus musculus was used for the present investigation. Four experimental groups were used as Group I-Normal adult, Group II-D-galactose induced, Group III-D-galactose induced plus Bacoside A treated and Group IV-Natural aging. The effect of Bacoside A was studied against lipid peroxidation during induced aging. The level of lipid peroxidation in the form of MDA formation was determined and measured in brain, heart and liver.

Results: The statistical data obtained were analyzed using one way ANOVA, control vs other groups and results were expressed as mean \pm SE. In Bacoside A treated group the lipid peroxidation level in heart, brain and liver was significantly decreased ( $\mathrm{p}<0.001$ ) compared to control group. A significant increase $(\mathrm{p}<0.0001)$ in the level of lipid peroxidation was observed in D-galactose induced mice. In natural aging group highly significant increase $(\mathrm{p}<0.0001)$ in initial lipid peroxidation, ascorbate dependent lipid peroxidation and spontaneous lipid peroxidation was observed.

Conclusion: The observations revealed that, lipid peroxidation was reversed in Bacoside A treated group which may be due to antioxidant property of Bacoside A. Thus Bacoside A is able to ameliorate the stress induced changes in lipid peroxidation during aging. The findings also provide a theoretical basis for the development of novel therapeutic formulations, such as antioxidant supplementation to boost antioxidant defenses in the body.

Keywords: Oxidative stress, Aging, Lipid peroxidation, D-galactose, Bacoside A, Antioxidant

(C) 2017 The Authors. Published by Innovare Academic Sciences Pvt Ltd. This is an open access article under the CC BY license (http://creativecommons.org/licenses/by/4.0/) DOI: http://dx.doi.org/10.22159/ijpps.2017v9i9.16874

\section{INTRODUCTION}

Lipid peroxidation is the product of chemical damage done to the lipid component of cell membranes by oxygen free radicals [1-3] This damage is thought to be a basic mechanism underlying many diverse disorders such as atherosclerosis, cancer, aging, rheumatic diseases, cardiac and cerebral ischemia, various liver problems and toxicity induced by harmful environmental factors. It has been considered that the lipid peroxidation damage is involved in aging and pathological disorders $[4,5]$. Reactive Oxygen Species (ROS) are constantly generated in living cells as a part of intracellular metabolic processes and induce oxidative damage to cell membranes, lipids, proteins and nucleic acids [6, 7]. The free radicals that contribute to the aging process are derived directly or indirectly from oxygen. As lipid peroxidation traditionally has been regarded as the major process that produces damage to oxygen radicals and the oxidized lipid residues are major components of lipofuscin, the fluorescent pigment that accumulates with age in most tissues [8-10]. Post mitotic cells are very susceptible to the oxidative damage due to their high consumption of oxygen and presence of fatty acids that are prone to peroxidation. Thus damage due to lipid peroxidation is evident in a wide range of degenerative diseases and aging $[6,11]$. A reducing sugar, D-galactose reacts with free amino groups of amino acids and proteins to form insoluble agglomerates called as advanced glycation end products, AGE's [12, 13]. The advanced glycation end products formed due to D-galactose accumulates in cells and provokes the formation of free radicals which are responsible for the pathogenesis of various diseases and aging as well [14].

Many researchers have focused on natural antioxidants, numerous crude extracts and pure natural compounds present in plants. A large amount of secondary metabolites are present in medicinal plants. Flavonoids, saponins and polyphenols in plants are a versatile group of antioxidants that protect against damage caused due to lipid peroxidation by directly neutralizing reactive oxygen species [15-22]. It is therefore important to study the effect of secondary metabolites on a particular tissue. Bacopa monnieri (L) traditionally used to treat various human ailments. It has been reported to have possible medicinal attributes as an antioxidative, antimicrobial, anti-aging and free radical scavenging activity [2328]. Triterpenoid saponins, the major components in Brahmi, were reported to be responsible for the cognitive enhancing activity of Brahmi [24, 26, 29]. The major bioactive dammarene type triterpenoid saponin isolated from the Bacopa monnieri (L), that carries the neuropharmacological activities, is Bacoside A [30]. In this context, the study has been carried out to evaluate the effect of Bacoside $\mathrm{A}$ on lipid peroxidation in D-galactose induced aging mice.

\section{MATERIALS AND METHODS}

\section{Chemicals and reagents}

D Galactose, Potassium chloride (KCl), Ascorbic acid, Ammonium ferrous sulphate (Mohr's salt), Trichloroacetic acid (TCA), Thiobarbituric acid (TBA) were purchased from LOBA chemie Pvt. Ltd., Mumbai, India.

\section{Animals}

Male mice (Mus musculus) of Swiss albino strain of different age groups were reared in animal house. Approval was obtained by the CPCSEA and IAEC (CPCSEA/PCL/23/2014-15). All instructions and rules of CPCSEA were followed. Animals were kept under a 12:12 hr L: D cycle and fed ad libitum a commercial diet provided by Pranav Agro Industries, Pune. Animals were divided into the following four experimental groups, six animals each group:

Group I-Normal adult (control) (12 Mo Age)

Group II-D-galactose induced (12 Mo Age)-injected with D-galactose subcutaneously for $56 \mathrm{~d}$ 
Group III-D-galactose induced+Bacoside A treated (12 Mo Age)injected with D-galactose subcutaneously and administered Bacoside A orally at a dose of $\mathrm{mg} / \mathrm{kg}$ body weight for $56 \mathrm{~d}$

Group IV-Natural aging (18-20 Mo Age).

\section{Plant}

The Bacoside A $\left(\mathrm{C}_{41} \mathrm{H}_{68} \mathrm{O}_{13}\right)$ was purchased from M/S Natural Remedies Pvt. Ltd. Banglore, India.

\section{Preparation of homogenate}

The experimental animals were sacrificed after completion of doses. The brain, heart and liver were dissected out. The brain tissues were separated as cerebral hemisphere and cerebellum. The homogenates were prepared by using $0.9 \%$ KCL and centrifuged at $3000 \mathrm{rpm}$ at $10^{\circ} \mathrm{C}$. The obtained homogenates were used for further study.

\section{Lipid peroxidation assay}

The rate of lipid peroxidation was measured by the method of Strove and Makarova 1980. The level of lipid peroxidation in the form of MDA formation was determined and measured in brain regions, heart and liver at $532 \mathrm{~nm}$.

\section{Statistical analysis}

The results obtained were analyzed by the SPSS software package version 20. The mean values obtained for the different groups were compared by one-way ANOVA, followed by Dunnett test, Normal adult (control) vs other groups. The results were expressed as mean $\pm \mathrm{SE}$ and $\mathrm{P}<0.001$ was considered as highly significant.

\section{RESULTS AND DISCUSSION}

In the present study, the level of lipid peroxidation in brain, heart and liver of experimental groups was measured. The lipid peroxidation in the form of MDA formation in cerebral hemisphere, cerebellum, heart and liver were depicted in table 1 and Graph No. 1,2,3,4. In Bacoside A treated group the lipid peroxidation level in heart, brain and liver was significantly decreased $(p<0.001)$ which some extent resembles as in the normal adult. A significant increase $(p<0.0001)$ in the level of lipid peroxidation was observed in D-galactose induced mice. In natural aging group highly significant increase $(\mathrm{p}<0.0001)$ in initial lipid peroxidation, ascorbate dependent lipid peroxidation and spontaneous lipid peroxidation was observed.
In vivo lipid peroxidation has been identified as a basic deteriorative reaction in cellular mechanisms of aging processes $[5,31]$. As highly reactive free radicals are not removed from the cell, the propagation of free radical reaction may be increasing exponentially in old age. The pattern of damage to proteins induced by peroxidizing lipid is similar to radiation damage [32]. Effect of age on lipid peroxidation in various parts of the rat brain was studied by Koudelova and Mourk, a significant increase in MDA production in cerebral cortex was observed [33]. Age related changes in lipid peroxidation were observed by Pawar, the lipid peroxidation was increased in old male mice than in adult male mice [34]. It was reported that feeding of Murraya koenigii and Brassica Juncea decreased the level of lipid peroxidation in liver and heart of rats [15]. The significant reduction in the level of lipid peroxidation was observed in rats liver and heart treated with methanol extract of Teramnus labialis [19].

When the level of D-galactose increases above the normal, it gets oxidized into hydrogen peroxide and aldehydes [35]. Increased level of it induces premature aging due to increased advanced glycation end products, decreases motor activity and stimulates diabetes [36]. It has been reported that $\mathrm{D}$-galactose responsible to deflate immune responses, accelerate oxidative stress by increasing lipid peroxidation and decline antioxidant enzyme activities by prevailing degeneration [37]. The study on aging showed that in D-galactose treated mice increased levels of lipid peroxidation indicates ageing associated changes since during aging there is increased production of reactive oxygen species, hence increased lipid peroxidation [38]. It was observed that the animals administered Petroselinum crispum extract along with D-galactose showed the significantly low level of MDA in the brain as compared to the D-galactose treated mice [11]. Increased malondialdehyde is an indication of increased lipid peroxidation in D-galactose treated mice that results due to increased oxidative stress $[39,40]$.

The results from our study revealed that the concentration of MDA in brain regions, heart and liver of D-galactose treated group was elevated as compared to control group. In the animals which received Bacoside A along with D-galactose, MDA level was significantly less in brain regions, heart and liver as compared to Dgalactose treated group. The results show that administration of Bacoside A brings about alterations in the level of lipid peroxidation in different tissues. The concentration of MDA decreased significantly in the brain, heart and liver of Bacoside A treated group hence Bacoside A has ameliorative effects on D-galactose induced mice. The level of lipid peroxides in Bacoside A administered group suggests that it can able to revert the effects caused due to Dgalactose and can maintain the concentration of MDA at the normal level during induced ageing.

Table 1: Formation of TBA reacting products in spontaneous, ascorbate dependent and initial lipid peroxidation (n mols malondialdehyde/mg tissue $/ 1 \mathrm{~h}$.) in cerebral hemisphere, cerebellum, heart and liver

\begin{tabular}{|c|c|c|c|c|c|c|c|c|c|c|c|c|}
\hline \multirow{2}{*}{$\begin{array}{l}\text { Organ } \\
\text { group }\end{array}$} & \multicolumn{3}{|c|}{ Cerebral hemisphere } & \multicolumn{3}{|c|}{ Cerebellum } & \multicolumn{3}{|l|}{ Heart } & \multicolumn{3}{|l|}{ Liver } \\
\hline & $\mathbf{X 1}$ & $\mathbf{X 2}$ & X3 & $\mathbf{X 1}$ & $\mathrm{X} 2$ & X3 & X1 & $\mathrm{X} 2$ & X3 & $\mathbf{X 1}$ & $\mathrm{X} 2$ & X3 \\
\hline Normal Adult & $\begin{array}{l}39.20 \\
\pm 0.100 \\
6\end{array}$ & $\begin{array}{l}9.502 \\
\pm 0.0213\end{array}$ & $\begin{array}{l}0.8263 \\
\pm 0.007 \\
5\end{array}$ & $\begin{array}{l}45.68 \\
\pm 0.013 \\
8\end{array}$ & $\begin{array}{l}6.678 \\
\pm 0.006 \\
0\end{array}$ & $\begin{array}{l}1.063 \\
\pm 0.024 \\
5\end{array}$ & $\begin{array}{l}31.49 \\
\pm 0.140 \\
7\end{array}$ & $\begin{array}{l}4.770 \\
\pm 0.005 \\
7\end{array}$ & $\begin{array}{l}0.6728 \\
\pm 0.001 \\
4\end{array}$ & $\begin{array}{l}41.13 \\
\pm 0.249 \\
3\end{array}$ & $\begin{array}{l}5.832 \\
\pm 0.014 \\
4\end{array}$ & $\begin{array}{l}1.345 \\
\pm 0.058 \\
5\end{array}$ \\
\hline $\begin{array}{l}\text { D-galactose } \\
\text { induced }\end{array}$ & $\begin{array}{l}43.92 \\
\pm 0.048 \\
2\end{array}$ & $\begin{array}{l}11.65 \\
\pm 0.0135\end{array}$ & $\begin{array}{l}1.513 \\
\pm 0.001 \\
6\end{array}$ & $\begin{array}{l}48.30 \\
\pm 0.033 \\
8\end{array}$ & $\begin{array}{l}14.87 \\
\pm 0.010 \\
0\end{array}$ & $\begin{array}{l}1.873 \\
\pm 0.002 \\
4\end{array}$ & $\begin{array}{l}39.95 \\
\pm 0.013 \\
5\end{array}$ & $\begin{array}{l}5.125 \\
\pm 0.012 \\
0\end{array}$ & $\begin{array}{l}1.013 \\
\pm 0.001 \\
0\end{array}$ & $\begin{array}{l}46.98 \\
\pm 0.007 \\
6\end{array}$ & $\begin{array}{l}9.055 \\
\pm 0.008 \\
8\end{array}$ & $\begin{array}{l}2.067 \\
\pm 0.000 \\
7\end{array}$ \\
\hline $\begin{array}{l}\text { D- } \\
\text { galactose+Bacosi }\end{array}$ & $\begin{array}{l}39.77 \\
\pm 0.154\end{array}$ & $\begin{array}{l}6.147 \\
\pm 0.0114\end{array}$ & $\begin{array}{l}0.5380 \\
\pm 0.000\end{array}$ & $\begin{array}{l}42.12 \\
\pm 0.078\end{array}$ & $\begin{array}{l}11.67 \\
\pm 0.011\end{array}$ & $\begin{array}{l}0.8865 \\
\pm 0.005\end{array}$ & $\begin{array}{l}29.33 \\
\pm 0.013\end{array}$ & $\begin{array}{l}4.858 \\
\pm 0.060\end{array}$ & $\begin{array}{l}1.090 \\
\pm 0.002\end{array}$ & $\begin{array}{l}31.65 \\
\pm 0.117\end{array}$ & $\begin{array}{l}7.237 \\
\pm 0.031\end{array}$ & $\begin{array}{l}1.649 \\
\pm 0.001\end{array}$ \\
\hline de A treated & 5 & 5 & 6 & 8 & 4 & 0 & 0 & 0 & 5 & 4 & 1 & 7 \\
\hline Natural aging & $\begin{array}{l}49.78 \\
\pm 0.006 \\
5\end{array}$ & $\begin{array}{l}14.29 \\
\pm 0.0061\end{array}$ & $\begin{array}{l}1.816 \\
\pm 0.123 \\
9\end{array}$ & $\begin{array}{l}52.90 \\
\pm 0.005 \\
7\end{array}$ & $\begin{array}{l}17.07 \\
\pm 0.020 \\
2\end{array}$ & $\begin{array}{l}2.328 \\
\pm 0.054 \\
3\end{array}$ & $\begin{array}{l}48.45 \\
\pm 0.186 \\
9\end{array}$ & $\begin{array}{l}6.702 \\
\pm 0.126 \\
9\end{array}$ & $\begin{array}{l}1.519 \\
\pm 0.038 \\
6\end{array}$ & $\begin{array}{l}50.47 \\
\pm 0.058 \\
9\end{array}$ & $\begin{array}{l}11.38 \\
\pm 0.121 \\
6\end{array}$ & $\begin{array}{l}3.169 \\
\pm 0.004 \\
0\end{array}$ \\
\hline
\end{tabular}

All values of D-galactose, induced, D-galactose+Bacoside A treated group and Natural aging group are compared with respect to the normal adult (control) group, Values are expressed as mean $\pm \mathrm{SE}(\mathrm{n}=6$ mice), X1-The rate of spontaneous lipid peroxidation in the homogenates $\mathrm{nmoles}$ of malondialdehyde formation during $1 \mathrm{~h}$. X2-The rate of ascorbate dependent non-enzymatic peroxidation in the homogenates nmoles of malondialdehyde formation during $1 \mathrm{~h}$. X3-The amount of malondialdehyde in the initial homogenate 

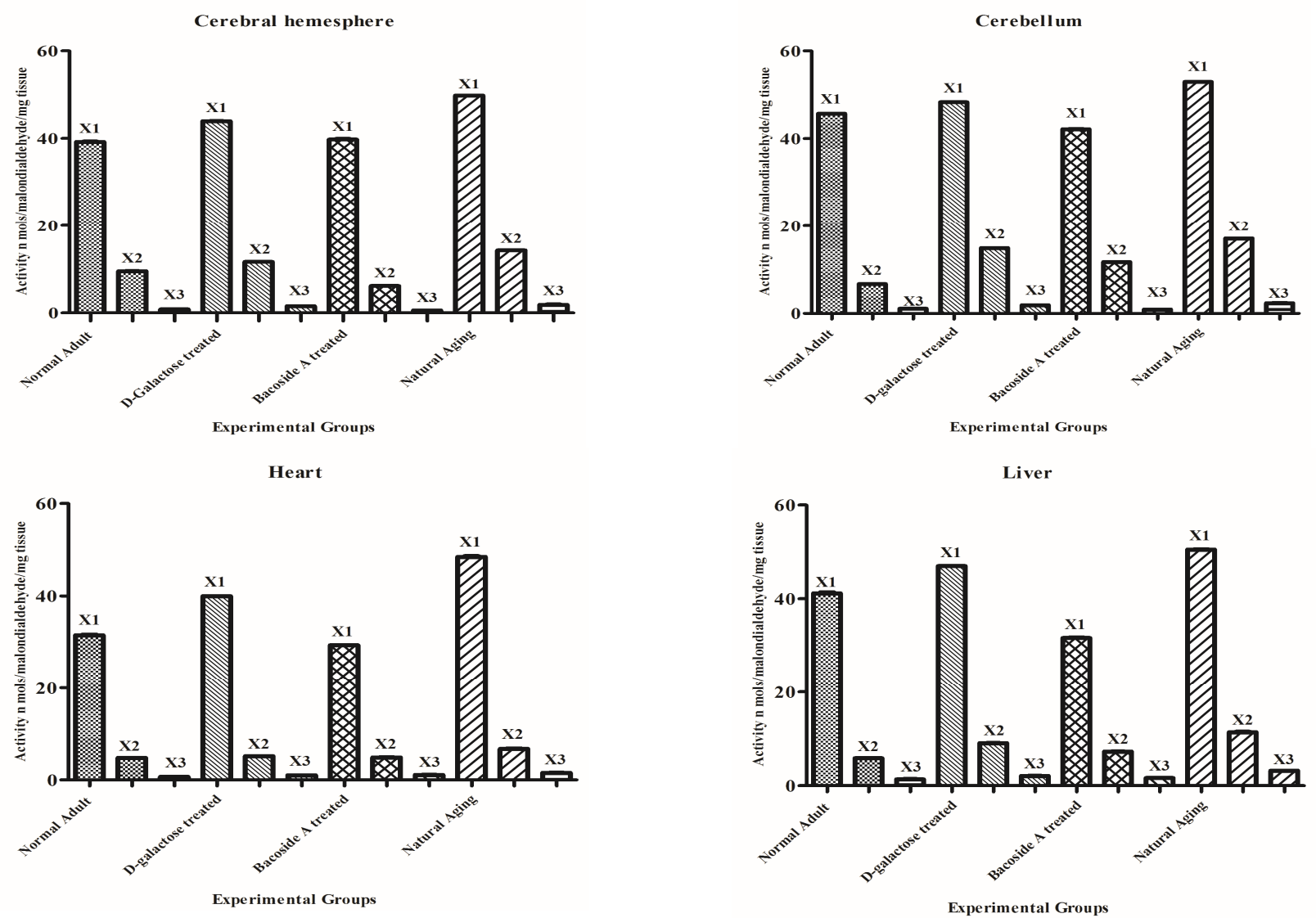

Fig. 1: Formation of TBA reacting products in spontaneous, ascorbate dependent and initial lipid peroxidation (n mols malondialdehyde/mg tissue/1h.) in Cerebral hemisphere, cerebellum, heart and liver

\section{CONCLUSION}

The present study concluded that increased level of lipid peroxidation may be due to formation advanced glycation end products by $\mathrm{D}$-galactose. Maximum protection against lipid peroxidation damage can be achieved by using sufficient concentrations of natural antioxidants. Thus, the present results suggest that Bacoside A may have the potential to reduce the formation of lipid peroxidation during induced aging.

\section{ACKNOWLEDGEMENT}

This research was financially supported by UGC, Delhi. We are grateful to Dr. Shivajirao Kadam, Vice Chancellor, Bharati Vidyapeeth Deemed University, Pune for his constant inspiration and Principal Dr. K. D. Jadhav, Yashwantrao Mohite College of Arts, Science and Commerce, Pune for providing facilities during research.

\section{AUTHORS CONTRIBUTION}

Authors are equally contributed in this work.

\section{CONFLICT OF INTERESTS}

The authors declare that there are no conflicts of interest

\section{REFERENCES}

1. Sister TF. Free radical mechanism in tissue injury. Biochem J 1984;222:1-15

2. Halliwell B, Gutteridge JM. The importance of free radicals and catalytic metal ions in human diseases. Mol Aspects Med 1985;8:89-193.

3. Sevanian A, Hochstein P. Mechanisms and consequences of lipid peroxidation in biological systems. Annu Rev Nutr 1985;5:365-90.

4. Harman D. Prolongation of life: Role of free radical reactions in aging. J Am Geriat Soc 1969;17:721-35.
5. Tappel AL. Will antioxidant nutrients slow aging processes? Geriatrics 1968;23:97-105.

6. Ames BN, Shigenaga MK, Hagen TM. Oxidants, antioxidants, and the degenerative diseases of aging. Proc Natl Acad Sci USA 1993;90:7915-22.

7. McCord JM. Human disease, free radicals, and the oxidant/antioxidant balance. Clin Biochem 1993;26:351-7.

8. Patro IK. Lipofuscinolysis by four neurotropic agents: a comparative study In: Perspectives in aging research, Biological, medical and Social. eds. R Singh. Today and tomorrow's Printers and Publishers, New Delhi; 1990. p. 133-6.

9. Brunk UT, Jones CB, Sohal RS. A novel hypothesis of lipofuscinogenesis and cellular aging based on interactions between oxidative stress and autophagocytosis. Mutat Res 1992;275:395-403.

10. Yu BP. In: BP Yu. Ed. Free radicals in aging, CRC Press; Boca Raton: 1993. p. 57-88.

11. Vora SR, Patil RB, Pillai MM. Protective effects of Petroselinum crispum (Mill) Nyman ex A. W. Hill leaf extract on D-galactoseinduced oxidative stress in mouse brain. Indian J Exp Biol 2009;47:338-42.

12. Munch G, Simm A, Double KL, Reiderer P. Alzheimer's Disease Review; 1996. p. 71-4.

13. Schmidt AM, Hori O, Cao R, Yan SD, Brett J, Wautier JL, et al. Diabetic dyslipidemia: basic mechanisms underlying the common hypertriglyceridemia and low HDL cholesterol levels. Diabetes 1996;45(Suppl 3):S27-30.

14. Hamada Y, Araki N, Kou N, Nakamura J, Horiuchi S, Hotta N. Rapid formation of advanced glycation end products by intermediate metabolites of the glycolytic pathway and polyol pathway. Biochem Biophys Res Commun 1996;228:539.

15. Khan BA, Abraham A, Leelamma S. Role of Murraya koenigii (Curry leaf) and Brassica Juncea (Mustard) in lipid peroxidation. Indian J Physiol Pharmacol 1996;40:155-8. 
16. Chithra V, Leelamma S. Coriandrum sativum changes the levels of lipid peroxides and activity of antioxidant enzymes in experimental animals. Indian J Biochem Biophys 1999;36:59-61.

17. Zhang $\mathrm{Q}$, Ning L, Zhou G, Lu X, Xu Z, Li Z. In vivo antioxidant activity of polysaccharide fraction from Porphyra haitanesis (Rhodephyta) in aging mice. Pharmacol Res 2003;48:151-5.

18. Fidan AF, Cingi CC, Karafakioglu YS, Utuk AE, Pekkaya S, Piskin FC. The levels of antioxidant activity, malondialdehyde and nitric oxide in cows naturally infected with Neospora caninum. J Anim Vet Adv 2010;9:1707-11.

19. Alagumanivasagam G, Muthu AK, Manavalan R. Antioxidant and lipid peroxidation effect of methanolic extract of the whole plant of Teramnus labialis (Linn.) in rat fed with high-fat diet. Int J Pharm Tech Res 2012;4:1233-7.

20. Jasuja N, Sharma P, Joshi SC. Ameliorating effect of Withania somnifera on acephate administered male albino rats. Afr J Pharm Pharmacol 2013;7:1554-9.

21. Kotebagilu NP, Palvai VR, Urooj A. Protective effect of selected medicinal plants against Hydrogen peroxide induced oxidative damage on biological substrates. Int J Med Chem 2014;1-7. http://dx.doi.org/10.1155/2014/861084

22. Porchelvan V, Venkatakrishnamurali R. The Aegle marmelos leaf extracts and whole leaf powder influencing effects on experimental animals tissue antioxidants and Atpases during chronic administration. Asian J Phytomed Clin Res 2015;3:13-23.

23. Nadkarni KM. Indian Materia Medica. Popular Prakashan Pvt Ltd. Mumbai; 1976. p. 624-5.

24. Singh HK, Rastogi RP, Srimal RC, Dhawan BN. Effects of bacoside A and B on avoidance response in rats. Phytother Res 1988;2:70-4.

25. Tripathi YB, Chaurasia S, Tripathi E, Upadyay A, Dubey GP. Bacopa monniera Linn. As an antioxidant: mechanism of action. Indian J Exp Biol 1996;34:523-6.

26. Singh HK, Dhawan BN. Neuropsychopharmacological effects of the Ayurvedic nootropic Bacopa monniera Linn. (Brahmi). Indian J Pharmacol 1997;29:S359-65.

27. Anbarasi K, Vani G, Balakrishna K, Shyamala Devi CS. Creatine kinase isoenzyme patterns upon chronic exposure to cigarette smoke: Protective effect of Bacoside A. Vascul Pharmacol 2005;42:57-61.

28. Pawar SS, Jadhav MG, Deokar TG. Study of phytochemical screening, physicochemical analysis and antimicrobial activity of Bacopa monnieri (L) extracts. Int J Pharm Clin Res 2016;8:1222-9.
29. Pawar SS, Jadhav MG. Determination and quantification of bacoside A from Bacopa monnieri L. by high-performance thin layer chromatography. Int J Pharm Phytopharm Res 2015;7:1060-5.

30. Garai S, Mahato SB, Obtani K, Yamasaki K. Dammarane type triterpenoid saponins from Bacopa monniera. Phytochemicals 1996;42:815-20.

31. Packer L, Deamer DW, Heath RL. Regulation and deterioration of structure in membranes. Adv Gerontol Res 1967;2:77.

32. Tappel AL. Biological antioxidant protection against lipid peroxidation damage. Am J Clin Nutr 1970;23:1137-9.

33. Koudelova J, Mourek J. The lipid peroxidation in various parts of the rat brain: effect of age, hypoxia and hyperoxia. Physiol Res 1994;43:169-73.

34. Pawar SS. Age related changes in brain acid phosphatase. Thesis Submitted to Shivaji University, Kolhapur; 2002.

35. Ho SC, Liu JH, Wu RY. Establishment of mimetic aging effect in mice caused by D-galactose. Biogerontology 2003;4:15-8.

36. Song X, Bao M, Li D, Li YM. Advanced glycation in D-galactose induced mouse aging model. Mech Aging Dev 1999;108:239-51.

37. Ida $\mathrm{H}$, Ishibashi $\mathrm{K}$, Reiser $\mathrm{K}$, Hjelmeland LM, Handa JT. Ultrastructural aging of the RPE Bruch's membranechoriocapillaris complex in the D-galactose-treated mouse. Investigative Ophthalmol Visual Sci 2004;45:2348-54.

38. Deshmukh AA, Gajare KA, Pillai MM. D-galactose induced aging in short duration: a quick model of accelerated ageing in mice. J Cell Tissue Res 2006;6:753-6.

39. Deshmukh AA, Gajare KA, Pillai MM. Six-month-old mice show increased lipid peroxidation and increased antioxidant enzymes with fifteen days treatment of $5 \% \mathrm{D}$ galactose: a quick model of oxidative stress for research on aging. Proc Comp Animal Physiol Stress Physiol. Osmania University, Hydrabad; 2005. p. 28.

40. Gajare KA, Deshmukh AA, Pillai MM. Protective effects of Bacopa monniera in D galactose induced oxidative stress in brain of female albino mice. Proc Comp Animal Physiol Stress Physiol. Osmania University, Hydrabad; 2005. p. 16.

\section{How to cite this article}

- Sushama Pawar, Manmohini Jadhav. Effect of bacoside an on lipid peroxidation in D-galactose induced aging mice. Int J Pharm Pharm Sci 2017;9(9):12-15. 